\title{
Correction
}

\section{Correction to: Effects of luffa and glass fibers in polyurethane-based ternary sandwich composites for building materials}

\author{
J. F. Jamaluddin ${ }^{1}$ - A. Firouzi ${ }^{2}$ M. R. Islam³ - A. N. A. Yahaya ${ }^{1}$
}

Published online: 29 November 2021

(c) Springer Nature Switzerland AG 2021

\section{Correction to: SN Applied Sciences (2020) 2:1207 https://doi.org/10.1007/s42452-020-3037-0}

In the affiliations of the first, third and fourth authors in the original article, the name of the university was incorrectly spelled. It is correctly spelled as Universiti Kuala Lumpur here.

Publisher's Note Springer Nature remains neutral with regard to jurisdictional claims in published maps and institutional affiliations.

The original article can be found online at https://doi.org/10.1007/s42452-020-3037-0.

M. R. Islam, remanraju@gmail.com; muhammad.remanul@unikl.edu.my | ${ }^{1}$ Malaysian Institute of Chemical and Bioengineering Technology, Universiti Kuala Lumpur, 78000 Bandar Alor Gajah, Melaka, Malaysia. ${ }^{2}$ Department of Biomedical Engineering, University of Houston, Texas, USA. ${ }^{3}$ Section of Instrumentation and Control Engineering, Malaysian Institute of Industrial Technology, Universiti Kuala Lumpur, 817500 Bandar Seri Alam, Pasir Gudang, Johor, Malaysia. 